\title{
PENGARUH PENAMBAHAN NATRIUM KLORIDA (NaCl) DAN WAKTU PERENDAMAN BUFFER FOSFAT TERHADAP PEROLEHAN CRUDE PAPAIN DARI DAUN PEPAYA (CARICA PAPAYA, L.)
}

\author{
Pinta Rizki Mala Hasibuan*, Mitha Alviyulita, Farida Hanum \\ Departemen Teknik Kimia, Fakultas Teknik Universitas Sumatera Utara \\ Jl. Almamater Kampus USU Medan, 20155 Indonesia \\ *Email : Kikipinta1@gmail.com
}

\begin{abstract}
Abstrak
Pepaya (Carica papaya L.) merupakan salah satu komoditas buah secara internasional, baik dalam bentuk buah segar maupun sebagai produk olahan. Daunnya yang berwarna hijau masih belum dimaanfaatkan secara maksimal. Daun pepaya mengandung enzim papain yang merupakan enzim protease yang sangat bermanfaat bagi industri. Papain merupakan enzim protease yang terkandung dalam getah pepaya, baik dalam buah, batang dan daunnya, sebagai enzim yang berkemampuan memecahkan molekul protein, saat ini papain menjadi produk yang sangat bermanfaat bagi kehidupan manusia, baik dirumah tangga maupun industri. Penelitian ini bertujuan untuk mengetahui pengaruh tingkat kejenuhan natrium klorida $(\mathrm{NaCl})$ dan perendaman buffer fosfat terhadap rendemen protease kasar daun pepaya. Penelitian ini memvariasikan waktu perendaman buffer fosfat dan tingkat kejenuhan natrium klorida $(\mathrm{NaCl})$. Analisis aktivitas protease dilakukan dengan menggunakan spektrofotometer UV-Vis untuk mengukur panjang gelombang dan nilai absorbansinya. Hasil penelitian terbaik diperoleh pada perendaman buffer fosfat 12 jam dengan konsentrasi natrium klorida $(\mathrm{NaCl}) 60 \%$ yaitu 272,8222 unit/ml. Pada analisa rendemen diperoleh kondisi terbaik pada saat perendaman buffer fosfat 36 jam pada konsentrasi $90 \%$ yaitu 43,5152\%. Pada analisa kadar air diperoleh kondisi terbaik pada saat perendaman 36 jam dengan konsentrasi $90 \%$ yaitu sebesar $37,4266 \%$.
\end{abstract}

Kata kunci: pepaya, natrium klorida, aktivitas protease, spektrofotometer UV, tirosin

\begin{abstract}
Papaya (Carica papaya L.) is one of the fruits of commodities internationally, either in the form of fresh fruit or as processed products. The leaves are green still not fully utilized. Papaya leaves contains papain enzyme which is a protease enzyme that very helpful for the industry. Papain is a protease enzyme contained in papaya latex, whether in fruit, stems and leaves, as an enzyme capable of solving the protein molecules, current papain into products that are beneficial to human life, either at home or industrial ladder. This study aims to determine the effect of the degree of saturation of sodium chloride and phosphate buffer to yield soaking rough papaya protease. This study varying the time of immersion phosphate buffer and saturation levels of sodium chloride. Analysis of protease activity was performed using UV-Vis spectrophotometer to measure the wavelength and absorbance values. The best research results obtained at $12 \mathrm{~h}$ immersion phosphate buffer with a concentration of sodium chloride $60 \%$ is 272.8222 unit / $\mathrm{ml}$. In the analysis of the rendemen obtained by the best condition at the time of immersion phosphate buffer for 36 hours at a concentration of $90 \%$ is $43,5152 \%$. In the analysis of moisture content obtained the best condition at the time of immersion of 36 hours at a concentration of $90 \%$ is $37.4266 \%$.
\end{abstract}

Keywords: papaya, sodium chloride, protease activity, spectrophotometer UV, tyrosine

\section{Pendahuluan}

Indonesia merupakan negara tropis dengan kekayaan flora yang berlimpah. Salah satu tanaman tropis yang banyak dijumpai di Indonesia adalah tanaman papaya (Carica papaya L) [9]. Semua bagian daripada pepaya dapat digunakan yaitu buah sebagai buah segar, daun untuk sayur dan makanan ternak, kayu untuk bahan bakar sedangkan getahnya mengandung enzim papain [14]. Papain terdapat hampir pada semua bagian tanaman pepaya, kecuali biji dan akarnya. Namun di antara bagian-bagian tanaman, konsentrasi terbesar berada pada batang dan buahnya. Diperkirakan lebih dari $50 \%$ kandungan papain pada tanaman papaya terdapat pada bagian-bagian tersebut [16].

Selain buah, bagian tanaman pepaya lainnya dapat dimanfaatkan untuk berbagai keperluan mulai sebagai bahan makanan dan minuman, obat tradisional, pakan ternak, industri penyamakan kulit, kosmetik, dan sebagainya. Bahkan bijinyapun dapat diolah lebih lanjut menjadi minyak dan tepung. Substansi lain yang banyak dimanfaatkan 
dalam dunia industri adalah getah pepaya yang mengandung papain yang dapat dihasilkan dari buah, batang, ataupun daun pepaya. Papain merupakan enzim proteolitik, yaitu enzim yang dapat mengurai dan memecah protein [12].

Adapun penelitian yang akan dilakukan yaitu pengaruh penambahan natrium klorida $(\mathrm{NaCl})$ dan waktu perendaman terhadap pembuatan papain dari daun pepaya (Carica Papaya L). Bahan baku yang digunakan dalam penelitian ini adalah daun pepaya, dimana daun papaya ini masih jarang dimanfaatkan orang sehingga dengan menggunakan daun pepaya akan meningkatkan nilai ekonomis bagi para petani pepaya. Selain itu pemanfaatan enzim dalam berbagai industri semakin meningkat. Salah satu enzim yang banyak digunakan dalam industri adalah enzim papain. Pada penelitian ini memvariasikan tingkat kejenuhan natrium klorida $(\mathrm{NaCl})$ dan waktu perendaman buffer fosfat. Adapun pemilihan pelarut $\mathrm{NaCl}$ ini karena harganya yang relatif murah dan mudah didapat, bahan yang tidak terlalu bahaya bila digunakan untuk makanan.

\section{Teori}

Pepaya (Carica papaya L.) merupakan salah satu komoditas buah secara internasional, baik dalam bentuk buah segar maupun sebagai produk olahan. Permintaan buah pepaya umumnya terus meningkat dari tahun ke tahun, berdasarkan data FAO pola konsumsi buah pepaya di Indonesia pada tahun 2005 mencapai 586340 ton dengan rata-rata peningkatan sebesar $16.67 \%$ [23].

Batang, daun, dan buah pepaya muda mengandung getah berwarna putih. Getah ini mengandung suatu enzim pemecah protein atau enzim proteolitik yang disebut papain. Papain termasuk enzim hidrolase, yaitu enzim yang mampu mengkatalis reaksi-reaksi hidrolisis suatu substrat (protein) [7].

Buah papaya mengandung enzim papain. Enzim papain merupakan senyawa aktif yang memiliki kemampuan mempercepat proses pencernaan protein. Enzim tersebut berfungsi sebagai proteolitik atau enzim pemecah protein. Papain merupakan enzim protease yang terkandung dalam getah pepaya, baik dalam buah, batang dan daunnya, sebagai enzim yang berkemampuan memecahkan molekul protein, saat ini papain menjadi produk yang sangat bermanfaat bagi kehidupan manusia, baik dirumah tangga maupun industri. Enzim papain sebagai protease sulfhidril dapat diaktifkan oleh zat- zat pereduksi dan menjadi tidak aktif jika terdapat zat pengoksidasi. Enzim papain memutus ikatan peptida pada residu asparagin-glutamin, glutamat-alanin, leusinvalin dan penilalanintirosin. Enzim tersebut akan bekerja secara optimal tergantung dari konsentrasi yang diberikan [11].

\section{Metodologi Penelitian}

Bahan baku yang digunakan dalam penelitian ini daun pepaya. Bahan kimia yang digunakan adalah aquadest, natrium klorida, kasein, asam trikhloroasetat (TCA), dan reagen ninhidrin.

Peralatan utama yang akan digunakan adalah blender, magnetic stirer, timbangan elektrik, alat-alat gelas, kertas saring whatman No. 4, sentrifius, dan spektrofotometer.

\section{Ekstrak Papain}

Daun papaya yang telah dihaluskan ditimbang sebanyak 100 gram dan dicampur dengan $200 \mathrm{ml}$ buffer fosfat $\mathrm{pH} 7$ dan didiamkan selama 0, 12, 24, dan 32 jam. Campuran kemudian disaring dengan menggukan kertas saring whatman No. 4, hasil residunya dibuang dan filtratnya ditambahkan natrium klorida pada tingkat kejenuhan 40, 50, 60, 70, 80 dan 90\%. Setelah itu filtrat distirer selama 20 menit pada temperatur ruangan. Kemudian disentrifius dengan kecepatan $8000 \mathrm{rpm}$ selama 7 menit pada temperatur $4^{0} \mathrm{C}$. Endapan yang terbentuk dilarutkan dengan 0,5 ml larutan 0,05 buffer fosfat $\mathrm{pH} 7$.

\section{Uji Aktivitas Protease}

Kualitas papain sangat ditentukan oleh kekuatan atau kemampuan papain untuk memecah protein. Kemampuan papain ini disebut aktivitas proteolitik (Proteolytic activity) yang sering dinyatakan dengan satuan unit [2]

Ekstrak papain sebanyak 0,1 $\mathrm{ml}$ dilarutkan dengan $0,1 \mathrm{ml}$ larutan buffer fosfat pH 7 dan dipreinkubasi pada temperature $37^{\circ} \mathrm{C}$ selama 5 menit dan ditambahkan dengan substrat (2\% kasein dalam 0,05 M buffer fosfat $\mathrm{pH}$ 7) sebanyak $0,1 \mathrm{ml}$. kemudian diinkubasi selama 10 menit pada temperatur $37^{\circ} \mathrm{C}$. kemudian reaksi dihentikan dengan menambahkan 0,2 $\mathrm{ml}$ asam trikhloroasetat (TCA) 0,4 M serta disentrifius pada kecepatan 2000 rpm selama 10 menit. Filtrat yang dihasilkan dipreinkubasi selama 10 menit. Setelah itu $1 \mathrm{ml}$ reagen ninhidrin ditambahkan dan didiamkan selama 30 menit. Lalu absorbansi dapat diukur dengan 
menggukan alat spektrofotometer. Sehingga aktivitas protease dapat dihitung dengan menggunakan persamaan [3] :

$$
\begin{aligned}
& \text { Aktivitas protease }=\frac{\text { tirosin } \times \mathrm{v}}{(\mathrm{p} \times \mathrm{q}) \times \mathrm{Fp}} \quad \ldots . . .(1) \\
& \begin{array}{ll}
\text { Keterangan } \quad: \\
\text { tirosin } & : \text { konsentrasi tirosin yang terbentuk } \\
\mathrm{v} & : \text { volume total sampel pada tiap } \\
& \text { tabung } \\
\mathrm{q} & : \text { waktu inkubasi } \\
\mathrm{p} & : \text { jumlah enzim }(\mathrm{mL}) \\
\mathrm{Fp} & : \text { faktor pengenceran }
\end{array}
\end{aligned}
$$

\section{Analisa Rendemen (OAC,1997)}

Penghitungan rendemen dilakukan dengan menimbang crude protease kering kemudian dibandingkan dengan berat sampel dikalikan $100 \%$. Penghitungan rendeman dapat menggunakan rumus sebagai berikut [1]:

$\%$ Rendemen $=\frac{\mathrm{A}}{\mathrm{B}} \times 100 \%$

Keterangan:

$$
\begin{array}{ll}
\text { A } & \text { : berat crude papain (gram) } \\
\text { B } & \text { : berat sampel daun pepaya } \\
& \text { (gram) }
\end{array}
$$

\section{Hasil dan Pembahasan}

Ekstrak Kasar Crude Papain dari Daun Pepaya (Carica papaya, l.)

Ekstrak papain merupakan hasil dari sentrifugasi yang diperoleh dari filtrat daun papaya. Hasil sentrifugasi yang diperoleh berupa sludge berwarna hijau pekat. Filtrat diperoleh dari daun papaya yang dihaluskan dengan penambahan buffer fosfat dan disaring dengan menggunakan kertas saring. Hasil penyaringan ditambahkan Natrium Klorida dengan konsentrasi $40 \%$ sampai $90 \%$ kemudian distirer selama 20 menit sampai natrium klorida tercampur semua pada suhu $4^{\circ} \mathrm{C}$. Pemilihan temperatur $4^{\circ}$ Cdilakukan untuk mencegah kerusakan enzim [10]. Garam ammonium sulfat sering digunakan untuk salting out protein enzim, karena kelarutannya sangat tinggi dan pada beberapa kasus memberikan efek menstabilkan enzim [6]. Sentrifugasi dilakukan selama 7 menit dengan kecepatan $8000 \mathrm{rpm}$ pada suhu $4^{\circ} \mathrm{C}$. Endapan yang diperoleh dipisahkan dengan menggunakan kertas saring dan direndam dengan larutan buffer fosfat $0.05 \mathrm{M} \mathrm{pH} 7$ sebanyak $0,5 \mathrm{ml}$ selama sesuai perlakuan $(0$ jam, 12 jam, 24 jam, dan 36 jam). Perendaman dilakukan untuk memisahkan protein enzim dariion logam dan molekul- molekul kecil, sehingga dapat memurnikan protein enzim [24].

$\begin{array}{lll}\text { Penentuan } & \text { Panjang } \\ \text { Maksimum } & \end{array}$

Dalam penentuan aktivitas protease, pertama-tama dilakukan penentuan panjang gelombang maksimum untuk larutan standar tirosin dengan menggunakan spektrofotometer UV. Pada larutan sampel dihasilkan panjang gelombang maksimum pada $274,80 \mathrm{~nm}$, dari rentang panjang gelombang 250-350 nm [13].

\section{Pembuatan Kurva Standar Larutan Tirosin}

Panjang gelombang maksimum yang dihasilkan digunakan untuk membuat kurva larutan standar tirosin. Kemudian, kurva standar tirosin dibuat dengan cara mengukur absorbansi larutan standar tirosin dengan konsentrasi 200 ppm sampai 1000 ppm dengan rentang 200 ppm dengan spektofotometer UV pada panjang gelombang maksimum. Dari data absorbansi larutan tirosin pada berbagai konsentrasi dibuat kurva larutan standar tirosin antara konsentrasi larutan tirosin terhadap absorbansi berdasarkan hukum Lambert Beer. Persamaan regresi kurva standar tirosin dinyatakan sebagai $\mathrm{y}=\mathrm{a}+\mathrm{bx}$, dengan ketentuan y adalah absorbansi dan $\mathrm{x}$ adalah konsentrasi larutan tirosin. Grafik konsentrasi larutan tirosin terhadap absorbansi dapat dilihat pada gambar 1 .

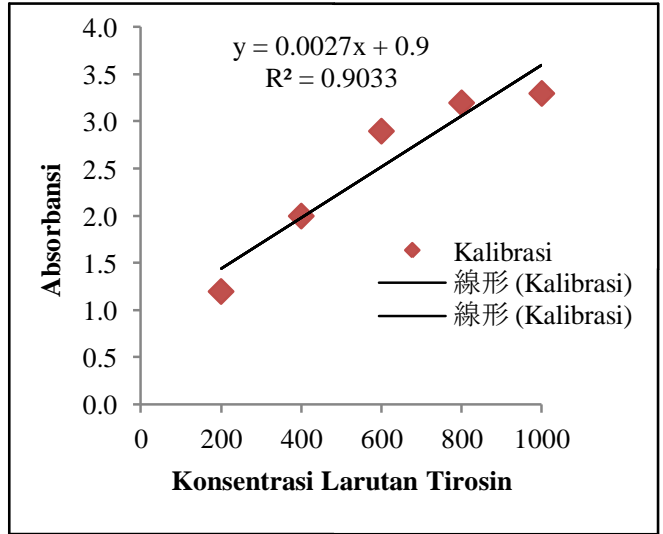

Gambar 1. Kurva kalibrasi Larutan Tirosin

Keabsahan kurva kalibrasi standar tirosin dapat diuji dengan menentukan harga koefisien korelasi $\left(\mathrm{R}^{2}\right)$ atau uji kelinieran yang menyatakan ukuran kesempurnaan hubungan antara konsentrasi larutan standar dan absorbansinya. Korelasi dinyatakan sempurna jika nilai $\mathrm{R}^{2}$ mendekati 1 . Berdasarkan data dan perhitungan didapatkan 
persamaan regresi linier larutan standar tirosin adalah $\mathrm{y}=0,0027 \mathrm{x}+0,9$ dengan nilai $\mathrm{R}^{2}=0,9033$. Harga $\mathrm{R}^{2}$ yang diperoleh mendekati 1, maka dapat disimpulkan bahwa nilai koefisien korelasi layak artinya titik-titik pada kurva kalibrasi mendekati kemiringannya.

\section{Analisa Rendemen}

Rendemen tepung papain kasar merupakan perbandingan antara berat tepung yang diperoleh dengan berat bahan awal. Menurut Vogel et al. [19] rendemen merujuk pada jumlah produk reaksi yang dihasilkan pada reaksi kimia. Sedangkan rendemen relatif digunakan untuk perhitungan efektivitas prosedur, dengan menghitung jumlah produk yang didapatkan dan membaginya berat awal sebelum proses [15].

Analisa rendemen dilakukan dengan cara menimbang ekstrak papain yang dihasilkan dan membandingkan dengan berat sampel daun pepaya. Rendemen yang diperoleh ditunjukna pada gambar 2.

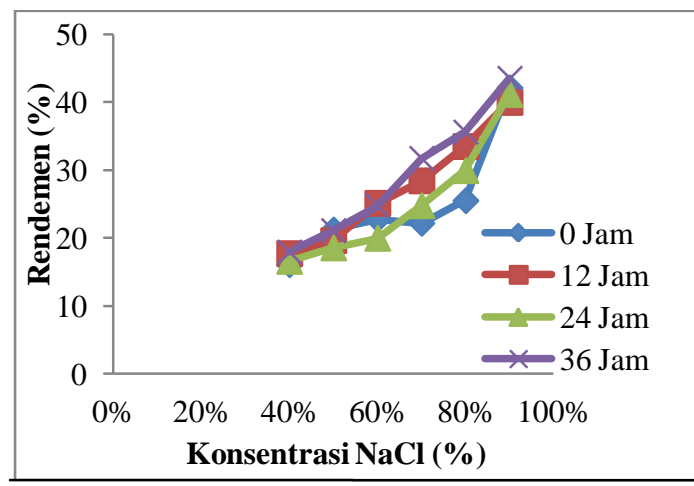

Gambar 2. Pengaruh Penambahan Konsentrasi Natrium Klorida ( $\mathrm{NaCl}$ ) dan Waktu Perendaman Buffer Fosfat terhadap Rendemen yang Dihasilkan

Dari gambar 2 dapat dilihat bahwa rendemen yang dihasilkan semakin meningkat seiring penambahan konsentrasi dan waktu perendaman yang dilakukan. Kondisi yang terbaik terjadi pada penambahan konsentrasi natrium klorida $90 \%$ pada waktu 36 jam sebesar 43,5152\%. Menurut Mathews and Hold [8] garam dalam larutan akan mengion dan menurunkan interaksi protein dengan pelarut sehingga interaksi antar molekul protein lebih tinggi dan akhirnya mengendap, ditambahkan oleh Trop [18] bahwa pada konsentrasi tinggi ionion garam akan berikatan dengan molekul air sehingga menurunkan interaksi molekul protein dengan pelarut (salting-out). Semakin lama waktu reaksi enzimatik maka semakin banyak produk yang terbentuk, yang juga berarti aktivitasnya semakin besar [2].

\section{Pengaruh Penambahan Konsentrasi Natrium Klorida ( $\mathrm{NaCl})$ dan Waktu Perendaman Buffer Fosfat Terhadap Aktivitas Protease}

Aktivitas enzim papain diperoleh dengan cara menghitung hasil absorbansi yang diperoleh dari hasil analisa spektrofotometer sampel dengan menggukan kurva standar tirosin yang telah ditetapkan sebelumnya dan dilakukan perhitungan dengan menggunakan Persamaan (1).

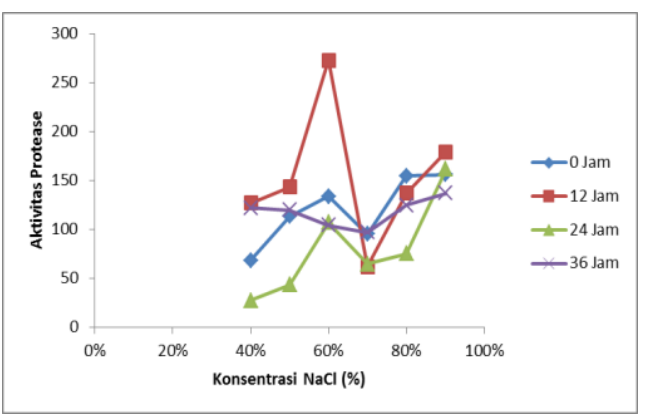

Gambar 3. Pengaruh Penambahan Konsentrasi Natrium Klorida $(\mathrm{NaCl})$ dan Waktu Perendaman Buffer Fosfat Terhadap Aktivitas Protease

Dari gambar 3 dapat dilihat bahwa aktivitas protease (papain) cenderung meningkat seiring bertambahnya konsentrasi dan waktu perendaman. Akan tetapi pada konsentrasi dan waktu tertentu aktivitas protease (papain) menurun, kemudian meningkat kembali apabila konsentrasi natrium klorida dan waktu perendaman ditambahkan terus-menerus.Aktivitas protease (papain)terbaik diperoleh pada konsentrasi $60 \%$ pada waktu 12 jam sebesar 272,8222 (U/ml). Kemudian ketika konsentrasi natrium klorida ditambahkan menjadi $70 \%$, aktivitas protease (papain) menurun menjadi $62,1333(\mathrm{U} / \mathrm{ml})$. Hal ini disebabkan karenaprotein enzimnya terdenaturasi sehingga daya kerja enzim menurun. Aktivitas enzim akan meningkat seiring bertambahnya konsentrasi substrat, setelah tercapai titik batas maka kecepatan reaksiakan mendekati tetapi tidak mencapai garis maksimum.Semakin lama waktu reaksi enzimatik maka semakin banyak produk yang terbentuk, yang juga berarti aktivitasnya semakin besar [2]. Dari data dapat 
disimpulkan bahwa kualitas papain ditentukan oleh tinggi rendahnya aktivitas proteasenya (papain) yang dimilikinya, semakin tinggi aktivitas proteasenya semakin tinggi pula kualitasnya dan sebaliknya, semakin rendah aktivitas proteasenya (papain) semakin rendah kualitasnya [20].

\section{Analisa Kadar Air}

Aktivitas proteolitik dan proses pengeringan sangat dipengaruhi oleh kadar air bahan. Menurut Winarno [21] kadar air bahan mempengaruhi laju reaksi enzimatis. Fennema [4] menambahkan pengurangan kadar air akan mempengaruhi banyaknya solute (bahan terlarut yang ada dalam bahan). Dalam hal ini bahan terlarut yang dimaksudkan adalah enzim papain kasar yang ada dalam bahan. Semakin banyak konsentrasi enzim yang didapat maka aktivitasnya akan semakin baik. Besarnya kadar air sangat penting. Kadar air mampu mempengaruhi daya awet bahan. Keberadaan air untuk pertumbuhan mikroba, terjadinya aktivitas enzimatik dan kimiawi sangat menentukan masa simpan makanan [5].

Kadar air merupakan salah satu parameter uji yang penting. Kadar air memerankan peranan penting dalam menentukan umur simpan. Selain itu pada proses pembuatan tepung papain menurut supiyatna [17] kadar air tepung papain jangan sampai lebih dari $9 \%$.

Analisa kadar air dilakukan sampai diperoleh berat konstan sampel yang dikeringkan. Dari hasil percobaan yang dilakukan diperoleh kadar air dari berbagai konsentrasi dan perendaman ditunjukkan pada gambar 4 .

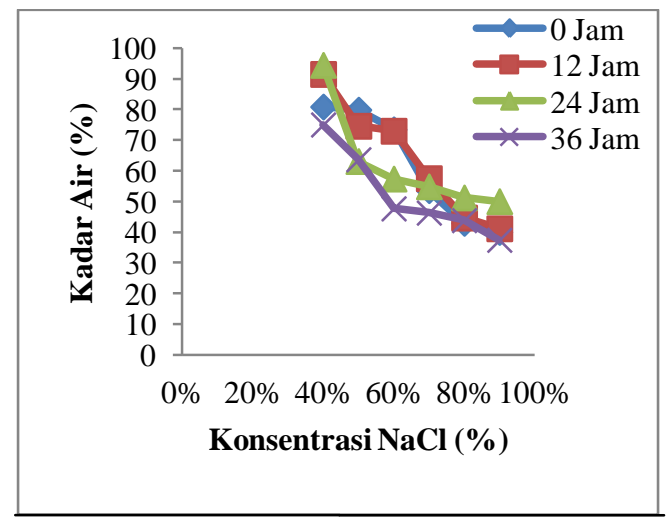

Grafik 4. Pengaruh Penambahan Natrium Klorida (NaCl)dan Waktu Perendaman Buffer Fosfat terhadap Kadar Air yang Dihasilkan
Dari gambar 4 dapat dilihat bahwa semakin besar konsentrasi natrium kloridadan waktu perendaman yang dilakukan maka kadar airnya semakin menurun.Kadar air terbaik terjadi pada konsentrasi natrium klorida $(\mathrm{NaCl}) 90 \%$ pada waktu 36 jam yaitu sebesar 37,4266\%. Hal ini disebabkan oleh ion-ion garam yang memiliki kelarutan lebih besar dibandingkan dengan protein sehingga ion garam akan menarik molekul air dari protein enzim. Kadar air bebas yang rendah menghambat difusi enzim atau substrat, akibatnya hidrolisis hanya terjadi pada bagian substrat yang langsung berhubungan dengan enzim [22].

Hasil percobaan yang dilakukan belum mencapai berat kering yang diinginkan yaitu sebesar > 9\%. Hal ini disebabkan karena sampel yang dianalisa kadar airnya berupa sludge.Banyak kandungan air pada sludge karena sludge yang dihasilkan belum dilakukan proses tahapan pengeringan menjadi tepung papain. Pembuatan papain hingga menjadi tepung perlu dilakukan proses lanjutanyaitu freeze drying.

\section{Kesimpulan}

Berdasarkan hasil penelitian dapat disimpulkan bahwa Pengaruh perendaman buffer fosfat dan konsentrasi natrium klorida $(\mathrm{NaCl})$ terhadap aktivitas protease tertinggi pada konsentrasi natrium klorida $60 \%$ pada perendaman 12 jam sebesar 272,8222 (unit/ml).

\section{Daftar Pustaka}

[1] AOAC, Official Methods Of Analysis Of The Association Of Offical Analitycal Chemist, $14^{\text {th }}$ ed AOAC. Inc. Arlington. Virginia, 1997.

[2] Askurrahman, Isolasi Karakterisasi Linamarase Hasil Isolasi Dari Umbi Singkong (Manihot Esculenta Craintz). Jurusan Teknologi Industri Pertanian, Fakultas Pertanian Universitas Trunojoyo, 2010.

[3] Enggel, J.; Meriandini, A. dan Natalia, L., Karakterisasi Protease EksTraseluler Clostridiun Bifermentans R14-1-b. Mikrobiologi Indonesia, 9 (1): 9-12, 2004.

[4] Fennema, Owen R. Fennema's Food Chemistry $4^{\text {ed }}$ Edition. Srinivasan Damodaran, Kirk L. Parkin Owen R. Fennema (editor). CRC Press. New York, 1996. 
[5] Fellow'sP. Food Processing Technology Principal and Practice Second Edition. CRC Press. New York, 2002.

[6] Fox, P.F. Food Enzymologi. Volume 1, Elsevier Applied Science, New York, 1991.

[7] Lukitasari D. Studi produksi papain enam genotipe pepaya. [Skripsi]. Departemen Budidaya Pertanian. Institut Pertanian Bogor, 2004.

[8] Mathews, C.K. and Van Holde, K.E., Biochemistry, The Benjamin/ Company Publishing Company Inc. United States of America, 1990.

[9] Mulyaningrum, Sri Redjeki Hesti. Isolasi, Karakterisasi, dan Amobilisasi Enzim Papain dari Getah Pepaya. Fakultas Matematika dan Ilmu Penfetahuan Alam. Universitas Diponegoro. 1999.

[10] Novianti Tri, Puji Ardiningsih, Winda Rahmalia, "Pengaruh Temperatur Terhadap Aktivitas Enzim Protease dari Daun Sansankng (Pycnarrhena Cauliflora Diels)” , JKK, tahun 2012, volume 1 (1), halaman 31-34, 2012.

[11] Nurhidayati, Tutik. Pengaruh Konsentrasi Enzim Papain Dan Suhu Fermentasi Terhadap Kualitas Keju Cottage. KAPPA (2003) Vol. 4, No.1, 13-17, 2003.

[12] Rahmadani, Kajian Pemanfaatan Enzim Papain dari Getah Pepaya (Carica papaya L.) untuk Melunakkan Daging. Universitas Negeri Medan, 2012.

[13] Risnawati Metty, and Sari Edi Cahyaningrum, " The Edition Effect Of The Metal Ions $\mathrm{Ca}^{2+}$ on The Papain Activities", UNESA Journal of Chemistry Vol. 2, No. 1, Surabay State University, 2013

[14] Sani. Panambahan Natrium, Bisulfit pada Kualitas Enzim Papain dari Getah Pepaya Secara MCU. Unesa University Press. Hal 1-41, 2008.

[15] Sudarmadji, S.B., Haryono dan Suhardi. Prosedur analisa Untuk Bahan Makanan dan Pertanian. PT. Liberty. Yogyagarta, 1997.

[16] Suliansyah, Irfan dan Syarif Auzar. Pengembangan Tanaman Pepaya sebagai Bahan Baku Agroindustri Papain. Lembaga Pengabdian masyarakat, Universitas Andalas, 2010.

[17] Supiyatna. Manfaat Getah Pepaya. http://halalguide.info. 2007, diakses tanggal 05 Mei 2014.
[18] Tropp, B.E. Biochemistry: concept and application, Brook/cole publishing company, United States of America, 1997.

[19] Vogel, A.1.,Tatchell A.R., Furnis, B.S Hannaford, A.J and P.W.G Smith. Vogel's Textbook of Practical Organic Chemistry, 5th Edition. Prentice Hall. New Jersey, 1996.

[20] Widjaja, E, A. Papain Zat Pelunak Daging, Bull.Kebun Raya., Vol. III, No. 1. 13-16, 1977.

[21] Winarno, F.G. Enzim Pangan. PUSPANGTEPA. IPB. Bogor. Hal. 107-110, 1995.

[22] Winarno F.G. Enzim Pangan, Penerbit Gramedia, Jakarta, 1983.

[23] Wiwit Widyastuti, Kajian Kualitas Buah Delapan Genotipe Pepaya Koleksi $P K B T$. Departemen Agronomi dan Hortikultura, Fakultas Pertanian IPB, 2009.

[24] Witono Yuli, Aulani am, Achmad Subagio dan Simon Bambang Widjanarko, "Pemurnian Parsial Enzim Protease Dari Geth Tanaman Biduri Menggunakan Amonium Sulphat", Jurnal Teknologi Pertanian, Vol. 7, No. 1 Universitas Brawijaya: Malang, 2006 